\title{
STRES PADA ORANG TUA YANG MEMILIKI ANAK DENGAN GANGGUAN SPEKTRUM AUTISME
}

\author{
Asri Mutiara Putri ${ }^{1}$, Woro Pramesti², Rani Dwi Hapsari ${ }^{3}$ \\ ${ }^{1}$ Program Studi Psikologi FK Universitas Malahayati, Bandar Lampung. Email: asri.mp@gmail.com \\ ${ }^{2}$ Rumah Sakit Umum Ahmad Yani, Metro, Lampung \\ 3Program Studi S1 Kedokteran FK Universitas Malahayati. Email:ranidwihapsari01@gmail.com
}

\section{ABSTRACT: STRESS EVALUATION IN PARENTS OF CHILDREN WITH AUTISME SPECTRUM DISORDER}

Introduction: Autism spectrum disorder (ASD) is a developmental disorder with symptoms like abnormalities in social function, communication, language, and repetitive behavior. Children with ASD) have many difficulties and developmental problem which can lead to stress in parents.

Purpose: The aim of this study wastodescribethe stres level ofparentsofchildren with autism spectrum disorder on disable school in Bandar Lampung.

Method: This study is a quantitative research with observational survey design. The sample is 39 parents of children with ASD that goes to disable school in Bandar Lampung. Perceivd Stress Scale (PSS) is used to assess stress.

Results: Result obtained form 39 parents, found that most of the parents have low level of stress (59\%), followed with moderate level of stress $(35,9 \%)$, and the least was high level of stress $(5,1 \%)$.

Conclusion: Although low level of stress found in this study, parents of children with ASD still need support from social environment to give good parenting for their children.

\section{Keyword: Stress, Parent, Spectrum Autism Disorder, Disable School}

Pendahuluan: Gangguan Spektrum Autisme (GSA) merupakan gangguan perkembangan dengan gejala antara lain abnormalitas pada fungsi sosial, komunikasi dan bahasa, serta perilaku repetitif. Anak penyandang GSA mengalami berbagai hambatan dan masalah dalam perkembangannya sehingga dapat menjadi sumber stres bagi orang tua.

Tujuan: Tujuan dari penelitian ini adalah untuk mengetahui gambaran stres pada orang tua yang memiliki anak dengan gangguan spektrum autisme di SLB se-Bandar Lampung.

Metode: Penelitian ini merupakan penelitian kuantitatif dengan desain survey observasional. Sampel penelitian berjumlah 39 orang tua dari anak penyandang GSA yang bersekolah di SLB di Bandar Lampung. Perceived Stress Scale (PSS) digunakan sebagai alat ukur untuk menilai stres.

Hasil: Hasil yang didapatkan dari total responden sebanyak 39 orang tua, sebagian besar responden memiliki tingkat stres ringan (59\%), diikuti dengan stres sedang $(35,9 \%)$, dan paling sedikit mengalami stres berat $(5,1 \%)$. Simpulan: Meskipun ditemukan bahwa stres yang dialami tergolong ringan, orang tua dari anak penyandang GSA tetap membutuhkan dukungan dari lingkungan untuk dapat memberikan pengasuhan yang baik bagi anaknya.

\section{Kata kunci: Stress, Orang Tua, Gangguan Spektrum Autisme, SLB.}

\section{PENDAHULUAN}

Memiliki anak adalah impian semua orang tua. Orangtua tentu saja mendambakan anak yang sehat baik secara fisik maupun jiwanya. Namun demikian, pada beberapa keluarga impian tersebut tidak dapat terwujud karena dikaruniai anak dengan gangguan spektrum autisme (GSA). GSA merupakan salah satu gangguan perkembangan yang muncul pada anak-anak. GSA ditandai dengan abnormalitas pada fungsi sosial, komunikasi dan bahasa, serta perilaku dan minat yang terbatas (Mash \& Wolfe, 2012).

Gejala GSA muncul sebelum usia 3 tahun dengan gejala yang muncul antara lain hambatan dalam berkomunikasi, penarikan diri yang ekstrem dari lingkungan sosial, dan tingkah laku yang terbatas dan berulang (Hallahan \& Kauffman, 2017). Gangguan dalam interaksi sosial muncul dalam bentuk perilaku kurang berminat pada orang dan enggan berinteraksi aktif dengan orang lain; tidak menampilkan ekspresi yang sesuai dengan situasi sosial, misalnya tersenyum saat tidak ada yang lucu; menghindari kontak mata, dan tidak bermain seperti anak normal lainnya. Lebih lanjut, hambatan dalam komunikasi tampil dalam perilaku tidak ingin berkomunikasi untuk tujuan sosial, menggunakan bahasa bukan untuk berkomunikasi, bicara seperti robot, mengulang-ngulang kata atau kalimat yang didengar, gangguan dalam komunikasi nonverbal, tidak memahami ucapan yang ditujukan 
kepada mereka, dan lain-lain. Kriteria diagnosis yang terakhir untuk anak GSA adalah munculnya perilaku yang terbatas dan berulang, contohnya hand flapping, memutar-mutar objek; preokupasi pada objek tertentu, serta tidak suka dengan perubahan di lingkungan maupun pada rutinitas harian (Mangunsong, 2009)

Selain gejala-gejala di atas, anak dengan GSA juga menampilkan gangguan dalam fungsi kognitif, persepsi sensori, motorik, afek atau mood, tingkah laku agresif dan berbahaya, serta gangguan tidur dan pola makan (Hallahan dan Kauffman, 2017). Ciri lain yang juga muncul pada awal kehidupan adalah adanya keterlambatan atau penyimpangan dalam perkembangan fungsi psikologis utama, contohnya terlambat bicara, tidak suka dipeluk atau digendong, hanya mau makanan dengan tekstur tertentu, dan lain-lain (Rutter, Bishop, Pine, Scott, Stevenson, Taylor, \& Thapar, 2011; Mangunsong, 2009).

Sampai saat ini penyebab GSA belum diketahui secara pasti, namun diduga penyebab lebih pada kerusakan neurobiologis dibandingkan masalah dalam hubungan interpersonal dengan orang tua (National Research Council 2001; Strock, 2004 dalam Hallahan \& Kauffman, 2017). Prevalensi anak yang menyandang GSA terus meningkat tiap tahunnya. Institut Nasional Kesehatan Mental dan Pusat Pengendalian dan Pencegahan Penyakit Amerika Serikat, menyatakan bahwa jumlah penyandang GSA meningkat pesat pada tahun 2009, 1 dari 100 anak didiagnosis mengalami GSA (Bararah, 2009). Di Indonesia sendiri data tentang penyandang GSA masih sedikit. Direktur Bina Kesehatan Jiwa Kementerian Kesehatan, Diah Setia mengatakan, diperkirakan terdapat 112.000 anak di Indonesia menyandang autisme, pada rentang usia sekitar 519 tahun (Rahmania, Nurwati, \& Taftazani, 2016). Lebih lanjut, Yayasan Autism Care Indonesia menyatakan bahwa jumlah anak penyandang GSA di Indonesia tahun 2010 adalah 53.200 anak (Judarwanto, dalam Fitriani \& Ambarini, 2013). Selain itu, RSU dr.Soetomo Surabaya menunjukkan jumlah penyandang GSA meningkat setiap tahun. Pada tahun 2009 ada 92 pasien GSA ke RSU dr. Soetomo dan pada tahun 2010 meningkat menjadi 100 pasien dan 125 pasien pada tahun 2011 (Anna, 2012).

Mengingat jumlah penyandang GSA yang semakin meningkat serta permasalahanpermasalahan yang muncul pada anak GSA, menjadi tantangan yang sangat besar bagi orang tua untuk mengasuh anak penyandang GSA. Anak dengan GSA memiliki kebutuhan yang sangat beragam. Untuk memberikan model pengasuhan yang tepat bagi anak GSA, orang tua perlu memahami bagaimana perilaku anak dan kesulitan apa saja yang dihadapi anak (Lambrechts, 2011). Selain memenuhi kebutuhan sehari-hari, kenyamanan dan kasih sayang bagi anak dengan GSA, orang tua harus belajar untuk melatih anak menguasai keterampilan dasar dan sosial yang lebih rumit jika dibandingkan anak normal lainnya.

Tantangan-tantangan yang besar dalam mengasuh anak GSA dapat menjadi salah satu faktor yang membuat orang tua mengalami stres.Stres merupakan respon individu yang meliputi stimulasi, kejadian, peristiwa, respon, dan interprestasi individu yang menyebabkan timbulnya ketegangan di luar kemampuan seseorang untuk mengatasinya (Santrock 2007; Kusumastuti, 2014).Penelitian telah menunjukkan bahwa memiliki anak GSA adalah prediktor terbesar stres dibandingkan dengan penyebab stress yang lain pada orang tua (Lyons, Leon, Phelps, \& Dunleavy, 2010). Lebih lanjut, penelitian sebelumnya juga menemukan ibu mengalami stres lebih besar dariayah dalam mengasuh anak GSA (Tehee, Hona, \& Hevey, 2009; Davis \& Carter, 2008).

Anak dengan gangguan spectrum GSA membutuhkan perhatian yang lebih sehingga tidak jarang keluarga memfokuskan segala sesuatunya pada anak tersebut. Hal ini akan membuat tugas orang tua menjadi semakin berat, karena meski keberadaan anak GSA membutuhkan perhatian lebih namun sebenarnya anggota keluarga lain pun juga membutuhkan perhatian. Stress yang dihadapi akan semakin tinggi, bahkan tidak jarang seorang ibu akan menyalahkan dirinya karena kondisi yang dialami oleh anaknya. Lebih lanjut, hasil penelitian sebelumnya juga menemukan bahwa ibu dengan anak GSA mengalami stress kronis yang jika disamakan, stress tersebut akan sama seperti stress yang dialami oleh pejuang pertempuran atau tentara (Seltzer dalam Rahmania, 2016., Hal ini menunjukkan betapa besarnya pengaruh kondisi anak GSA terhadap keberfungsian ibu dan keluarga.

Stres yang dialami ibu dapat menyebabkan ibu mengalami gangguan dalam proses pengasuhan yang pada akhirnya juga dapat berdampak buruk bagi perkembangan anak GSA itu sendiri. Stres pada dasarnya memiliki dua dampak,

Asri Mutiara Putri1Program Studi Psikologi FK Universitas Malahayati, Bandar Lampung. Email: asri.mp@gmail.com Woro Pramesti² Rumah Sakit Umum Ahmad Yani, Metro Lampung.

Rani Dwi Hapsari ${ }^{3}$ Program Studi S1 Kedokteran FK Universitas Malahayati Bandar Lampung . Email: ranidwihapsari01@gmail.com 
pertama dampak secara fisik berupa penurunan sistem kekebalan tubuh sehingga lebih mudah terserang penyakit, yang kedua adalah dampak secara psikis yaitu timbul perasaan negatif pada individu yang mengalami stress. Perasaan negatif ini akan menjadikan mereka mudah murung, kesepian, sedih, dendam, benci dan merasa tidak berguna. Stres yang berat atau kronis juga dapat menyebabkan seseorang kehilangan motivasi dan tujuan hidup, merasa hidup tidak bermakna serta dapat menyebabkan seseorang tidak mampu merasakan kebahagiaan dalam hidupnya (Alloy, Acocella dan Bootzin, 1996; Safaria, 2005). Hal ini yang juga dapat terjadi pada orang tua dengan anak GSA. Stres yang berkepanjangan dapat mengganggu pola pengasuhan dan hubungan keluarga. Pada kasus yang ekstrem, ibu yang mengalami stres dalam mengasuh anak GSAjuga bisa melakukan penelantaran bahkan kekerasan kepada anaknya (Sa'diyah, 2016). Disisi lain, stres pengasuhan juga akan menghambat pekerjaan yang biasa dilakukan ibu sehari-hari. lbu yang tidak bisa menerima kenyataan atas kondisi anaknya hanyaakan terpuruk dan bahkan tidak mau melakukan apapun untuk mendukung perkembangan anaknya. Akibatnya,ibu hanya berdiam diri dan kondisi keterbelakangan anak semakin parah (Sa'diyah, 2016).

Melihat besarnya dampak stres yang dialami orang tua terhadap pengasuhan dan perkembangan anak GSA, peneliti menganggap penting untuk mencari tahu lebih lanjut tentang gambaran stres pada orang tua yang memiliki anak GSA. Di provinsi Lampung sendiri, masih sangat sedikit penelitian yang dilakukan terkait dengan anak-anak berkebutuhan khusus. Penelitian ini diharapkan dapat memberikan sumbangan informasi bagi perkembangan ilmu pengetahuan khususnya dalam bidang psikologi anak berkebutuhan khusus. Selain itu, penelitian ini juga diharapkan dapat memberi gambaran informasi bagi keluarga dengan anak GSA sehingga dapat dilakukan langkah pencegahan terhadap stres yang dialami oleh orang tua dalam mengasuh anak GSA.

\section{METODE PENELITIAN}

Penelitian ini merupakan penelitian kuantitatif dengan desain survey observasional. Penelitian dilakukan terhadap 39 orang tua dari anak penyandang GSA yang bersekolah di SLB di Bandar Lampung, yaitu SLB Dharma Bakti, SLB IslamTerpaduBaitulJannah, SLB Growing Hopedan SLB Mazaya. Strespada orang tuadiukurdengan Perceived Stress Scale (PSS) yang disusun oleh Sheldon Cohen (1994) yang terbagi menjadi 3 aspek, yaitu tentang perasaan tidak terprediksi (feeling of unpredictability), perasaan tidak terkontrol (feeling of uncontrollability), dan perasaan tertekan (feeling of overloadded). Data hasil penelitian kemudian dalam bentuk distribusi frekuensi.

\section{HASIL}

\section{Karakteristik Responden}

Tabel 1. Distribusi Frekuensi Karakteristik Responden Berdasarkan Usia ( $N=39)$

\begin{tabular}{ccc}
\hline Usia & Jumlah & Persentase \\
\hline 26-35 Tahun & 4 & 10.3 \\
36-45 Tahun & 19 & 48.7 \\
46-55 Tahun & 14 & 35.9 \\
56-65 Tahun & 2 & 5.1 \\
\hline Total & 39 & 100.0 \\
\hline
\end{tabular}

Dari tabel 1 diatas ditemukan bahwa dari 39 responden, sebagian besar orang tua yang memiliki anak penyandang GSA di SLB di Bandar Lampung berusia 36-45 tahun (48,7\%).

Tabel 2. Distribusi Frekuensi Karakteristik Responden Berdasarkan Jenis Kelamin ( $\mathrm{N}=39$ )

\begin{tabular}{ccc}
\hline Jenis Kelamin & Jumlah & Persentase \\
\hline Laki-laki & 11 & 28,2 \\
Perempuan & 28 & 71,8 \\
\hline Total & 39 & 100.0 \\
\hline
\end{tabular}

Asri Mutiara Putri1Program Studi Psikologi FK Universitas Malahayati, Bandar Lampung. Email: asri.mp@gmail.com Woro Pramesti2Rumah Sakit Umum Ahmad Yani, Metro Lampung.

Rani Dwi Hapsari3 ${ }^{3}$ Program Studi S1 Kedokteran FK Universitas Malahayati Bandar Lampung . Email: ranidwihapsari01@gmail.com 
Dari tabel 2 diatas didapatkan bahwa dari 39 responden, sebagian besar orang tua yang menjalankan peran pengasuh untuk anak penyandang GSA di SLB di Bandar Lampung berjenis kelamin perempuan atau ibu $(71,8 \%)$.

Tabel 3. Distribusi Frekuensi Karakteristik Responden Berdasarkan Tingkat Pendidikan ( $N=39$ )

\begin{tabular}{ccc}
\hline Pendidikan & Jumlah & Persentase \\
\hline Pendidikan Rendah & 13 & 33,3 \\
Pendidikan Menengah & 16 & 41,0 \\
Pendidikan Tinggi & 10 & 25,6 \\
\hline Total & $\mathbf{3 9}$ & $\mathbf{1 0 0 . 0}$ \\
\hline
\end{tabular}

Dari tabel 3 diatas didapatkan bahwa dari 39 responden, sebagian besar orang tua yang memiliki anak penyandang GSA di SLB di Bandar Lampung memiliki latar belakang pendidikan menengah atau SMA sederajat $(41 \%)$.

Tabel 4. Distribusi Frekuensi Karakteristik Responden Berdasarkan Pekerjaan ( $\mathrm{N}=39$ )

\begin{tabular}{ccc}
\hline Pekerjaan & Jumlah & Persentase \\
\hline Bekerja & 11 & 28,2 \\
Tidak Bekerja & 28 & 71,8 \\
\hline Total & 39 & 100.0 \\
\hline
\end{tabular}

Dari tabel 4 diatas didapatkan bahwa dari 39 responden, sebagian besar orang tua yang memiliki anak penyandang GSA di SLB di Bandar Lampung tidak bekerja atau ibu rumah tangga $(71,8 \%)$.

Tabel 5. Distribusi Frekuensi Karekteristik Responden Berdasarkan Usia Anak (N=39)

\begin{tabular}{ccc}
\hline Usia & Jumlah & Persentase \\
\hline 5-11 Tahun & 18 & 46,2 \\
12-16 Tahun & 17 & 43,6 \\
17-25 Tahun & 4 & 10,3 \\
\hline Total & $\mathbf{3 9}$ & $\mathbf{1 0 0 . 0}$ \\
\hline
\end{tabular}

Dari tabel 5 diatas didapatkan bahwa dari 39 responden, sebagian besar orang tua memiliki anak penyandang GSA berusia 5-11 tahun $(43,25)$.

Tabel 6. Distribusi Frekuensi Karakteriktik Responden Berdasarkan Jenis Kelamin Anak ( $N=39$ )

\begin{tabular}{ccc}
\hline Jenis Kelamin & Jumlah & Persentase \\
\hline Laki-laki & 24 & 61,5 \\
Perempuan & 15 & 38,5 \\
\hline Total & 39 & $\mathbf{1 0 0 . 0}$ \\
\hline
\end{tabular}

Dari tabel 6 diatas didapatkan bahwa dari 39 responden, sebagian besar orang tua memiliki anak penyandang GSA berjenis kelamin laki-laki (61,5\%).

Asri Mutiara Putri1Program Studi Psikologi FK Universitas Malahayati, Bandar Lampung. Email: asri.mp@gmail.com Woro Pramesti2Rumah Sakit Umum Ahmad Yani, Metro Lampung.

Rani Dwi Hapsari3 Program Studi S1 Kedokteran FK Universitas Malahayati Bandar Lampung . Email: ranidwihapsari01@gmail.com 
Tabel 7. Distribusi Frekuensi Karakteristik Responden Berdasarkan Tingkat Pendidikan Anak (N=39)

\begin{tabular}{ccc}
\hline Kelas & Jumlah & Persentase \\
\hline SD & 27 & 69,2 \\
SMP & 8 & 20,5 \\
SMA & 4 & 10,3 \\
\hline Total & 39 & 100.0 \\
\hline
\end{tabular}

Dari tabel 7 diatas didapatkan bahwa dari 39 responden, sebagian besar orang tua memiliki anak penyandang GSA sedang menjalani pendidikan level SD $(69,2 \%)$.

\section{Analsis Tingkat Stress}

Tabel 8. Distribusi Frekuensi Responden Berdasarkan Tingkat Stres ( $N=39$ )

\begin{tabular}{ccc}
\hline Tingkat Stres & Jumlah & Persentase \\
\hline Tingkat Stres Ringan & 23 & 59,0 \\
Tingkat Stres Sedang & 14 & 35,9 \\
Tingkat Stres Berat & 2 & 5,1 \\
\hline Total & $\mathbf{3 9}$ & $\mathbf{1 0 0 . 0}$
\end{tabular}

Dari tabel 8 diatas didapatkan bahwa dari 39 responden, sebagian besar orang tua yang memiliki anak penyandang GSA mengalami stres ringan (59\%).

Tabel 9. Rerata Aspek Stress

\begin{tabular}{ccc}
\hline Aspek Dukungan Sosial & Skor & Mean \\
\hline Perasaan Tidak Terprediksi & 233 & 58,2 \\
Perasaan Tidak Terkontrol & 155 & 51,6 \\
Perasaan Tertekan & 167 & 55,6 \\
\hline Total & $\mathbf{5 5 5}$ & \\
\hline
\end{tabular}

Dari tabel 9 diatas didapatkan bahwa, orang tua yang memiliki anak penyandang GSA mengalami perasaan tidak terprediksi sebagai aspek stres yang paling dominan $(58,2 \%)$.

\section{DISKUSI}

Berdasarkan hasil penelitian ditemukan bahwa orang tua yang memiliki anak penyandang GSA sebagian besar mengalami stres ringan. Stres ringan termasuk tingkat stres yang sering terjadi dalam kehidupan sehari-hari. Stres dalam kategori ringan dapat membantu individu menjadi lebih waspada dan mampu mencegah munculnya berbagai kemungkinan yang akan terjadi dari masalah atau tekanan yang muncul. Individu yang mengalami stres ringan dapat menampilkan perilaku semangat kerja berlebihan, mudah lelah dan tidak bisa santai. Stres ringan tidak akan menimbulkan penyakit kecuali jika dihadapi terus menerus (Atziza, 2015). Pada orang tua anak autis stres ringan dapat mendorong orang tua untuk meningkatkan usahanya dalam pengasuhan anak penyandang GSA. tingkat stres dalam kategori ringan yaitu sebanyak 23 responden $(59,0 \%)$. Tingkat stres terbagi menjadi beberapa aspek yaitu aspek perasaan tidak terprediksi, aspek perasaan tidak terkontrol dan aspek perasaan tertekan (Cohen, 1994). Dari hasil penelitian didapatkan aspek tertinggi yaitu aspek perasaan tidak terprediksi dengan skor rata-rata 58,2. Aspek perasaan tidak terprediksi yaitu orang tua tidak mampu memprediksi peristiwa yang terjadi dalam kehidupannya secara tiba-tiba, maka orang tua tersebut akan menjadi tidak berdaya dan merasa putus asa sehingga hal ini yang mengakibatkan munculnya stres (Cohen, 1994).

Hasil penelitian ini tidak sejalan dengan beberapa hasil penelitian sebelumnya yang menunjukkan bahwa orang tua dari anak penyandang GSA cenderung mengalami stres yang

Asri Mutiara Putri1Program Studi Psikologi FK Universitas Malahayati, Bandar Lampung. Email: asri.mp@gmail.com Woro Pramesti²Rumah Sakit Umum Ahmad Yani, Metro Lampung.

Rani Dwi Hapsari3 ${ }^{3}$ Program Studi S1 Kedokteran FK Universitas Malahayati Bandar Lampung . Email: ranidwihapsari01@gmail.com 
tinggi (Schieve, Blumberg, Rice, Visser dan Boyle, 2007; Hayes, S. A., \&Watson, S. L., 2013); BakerEriczén, M. J., Brookman-Frazee, L., \& Stahmer, A., 2005 ). Namun demikian, terdapat pula hasil penelitian sebelumnya yang juga menemukan hal yang serupa dengan penelitian ini bahwa meskipun orang tua yang memiliki anak penyandang GSA mengalami stres yang lebih tinggi dibandingkan orang tua dari anak normal, tetapi tingkat stres tersebut tidak berbeda secara signifikan (Estes, $A$., Olson, E., Sullivan, K., Greenson, J., Winter, J., Dawson, G., \& Munson, J., 2013). Salah satu faktor yang berhubungan dengan rendahnya tingkat stres orang tua anak penyandang GSA dalam penelitian ini adalah karakteristik usia orang tua. Berdasarkan tabel 1 dapat dilihat bahwa sebagian besar responden berusia 36 sampai 45 tahun. Rentang usia tersebut berada dalam tahap usia dewasa, dimana usia individu memulai tanggung jawab dan komitmennya serta dianggap lebih berpengalaman menetapkan keputusan, sehingga lebih mampu mengelola stressor dan mampu mengarahkan sumber stres ke arah yang positif (Supriat \& Selvitriana, 2018). Lebih lanjut usiadari anak penyandang GSA juga dapat berhubungan dengan rendahnya tingkat stres yang dialami orang tua. Dalam penelitian ini ditemukan anak penyandang GSA sebagian besar berusia 5-11 tahun (lihat tabel 5). Hal ini menunjukkan bahwa anak penyandang GSA sudah berada pada usia sekolah sehingga orang tua GSA sudah mulai beradaptasi dengan kondisi anaknya dan karena sampel dalam penelitian ini bersekolah di SLB dapat diasumsukan anak penyandang GSA juga sudah memperoleh penanganan terhadap kondisinya sehingga tekanan yang dirasakan orang tua tidak begitu berat.

\section{SIMPULAN DAN SARAN}

Sebagian besar orang tua dari anak penyandang GSA di SLB se-Bandar Lampung mengalami stres ringan. Dukungan sosial kepada orangtua sebaiknya terus ditingkatkan sehingga orang tua dapat mengelola masalah yang dihadapinya dalam mengasuh anak penyandang GSA. Selain itu, pihak sekolah diharapkan dapat melakukan sosialisasi kepada orang tua terkait gangguan spektrum autisme sehingga dapat menjadi bahan masukan bagi orangtua dalam mengasuh anaknya. Untuk penelitian selanjutnya diharapkan dapat melakukan penelitian dengan melihat variabel yang lebih khusus yaitu stres pengasuhan sehingga dapat diperoleh informasi yang lebih akurat tentang kondisi stres yang dialami orang tua. Penelitian selanjutnya juga dapat meneliti faktor lain yang berhubungan dengan tingkat stres pada orang tua penyandang GSA, seperti status sosial ekonomi, tingkat pengetahuan, dan dukungan sosial.

\section{DAFTAR PUSTAKA}

Alloy, L. B., Riskind, J. H., \& Manos, M. J. (2005). Abnormal psychology: Current perspectives (Vol. 278). McGraw Hill.

Anna, L.K. (2012). Logam berat dapat picu autisme. Kompas [on-line]. Diakses dari http://health.kompas.com/read/2012/11/01/0 9055083/Logam.Berat.Dapat.Picu.Autisme

Atziza, R. (2015). Faktor-Faktor yang Mempengaruhi Kejadian Stres dalam Pendidikan Kedokteran. Jurnal Agromedicine, 2(3), 317-320

Baker-Ericzén, M. J., Brookman-Frazee, L., \& Stahmer, A. (2005). Stress levels and adaptability in parents of toddlers with and without AUTISm spectrum disorders. Research and practice for persons with severe disabilities, 30(4), 194-204

Bararah, F.V., (2009). 1 dari 100 anak menderita autis. Detik Health [on- line]. Diakses dari http://health.detik.com/read/2009/10/06/1509 10/1216319/764/1-dari-100-anak-menderitaautis.

Cohen, S., Kamarck, T., \& Mermelstein, R. (1994). Perceived stress scale. Measuring stress: $A$ guide for health and social scientists, 235283.

Davis, N. O., \& Carter, A. S. (2008). Parenting stress in mothers and fathers of toddlers with autism spectrum disorders: Associations with child characteristics. Journal of autism and developmental disorders, 38(7), 1278

Estes, A., Olson, E., Sullivan, K., Greenson, J., Winter, J., Dawson, G., \& Munson, J. (2013). Parenting-related stress and psychological distress in mothers of toddlers with AUTISm

Asri Mutiara Putri1Program Studi Psikologi FK Universitas Malahayati, Bandar Lampung. Email: asri.mp@gmail.com Woro Pramesti2Rumah Sakit Umum Ahmad Yani, Metro Lampung.

Rani Dwi Hapsari3 ${ }^{3}$ Program Studi S1 Kedokteran FK Universitas Malahayati Bandar Lampung . Email: ranidwihapsari01@gmail.com 
spectrum disorders. Brain and Development, 35(2), 133-138.

Fitriani, A., \& Ambarini, T. K. (2013). Hubungan antara hardiness dengan tingkat stres pengasuhan pada ibu dengan anak AUTIS. Jurnal Psikologi Klinis dan Kesehatan Mental, 2(2).

Hayes, S. A., \& Watson, S. L. (2013). The impact of parenting stress: A meta-analysis of studies comparing the experience of parenting stress in parents of children with and without AUTISm spectrum disorder. Journal of AUTISm and developmental disorders, 43(3), 629-642.

Kauffman, J. M., Hallahan, D. P., \& Pullen, P. C. (2017). Handbook of special education. Routledge.

Lambrechts, G., Van Leeuwen, K., Boonen, H., Maes, B., \& Noens, I. (2011). Parenting behaviour among parents of children with autism spectrum disorder. Research in Autism Spectrum Disorders, 5(3), 11431152.

Lyons, A. M., Leon, S. C., Phelps, C. E. R., \& Dunleavy, A. M. (2010). The impact of child symptom severity on stress among parents of children with ASD: The moderating role of coping styles. Journal of Child and Family Studies, 19(4), 516-524.

Mangunsong, F. (2009). Psikologi dan Pendidikan Anak Berkebutuhan Khusus Jilid Kesatu. Depok: LPSP3 UI.

Mash, E., \& Wolfe, D. (2012). Abnormal child psychology. Cengage Learning.
Rahmania, R., Nurwati, N., \& Taftazani, B. M. (2016). STRATEGI KOPING IBU DENGAN ANAK GANGGUAN SPEKTRUM AUTISME:(STUDI KASUS: ORANGTUA MURID TAMAN KANAN-KANAK MUTIARA BUNDA). Prosiding Penelitian dan Pengabdian kepada Masyarakat, 3(3), 334.

Rutter, M. J., Bishop, D., Pine, D., Scott, S., Stevenson, J. S., Taylor, E. A., \& Thapar, A. (2011). Rutter's child and adolescent psychiatry. John Wiley \& Sons.

Sa'diyah, S. (2016). Gambaran psychological wellbeing dan stres pengasuhan ibu dengan Anak AUTIS. Malang: Universitas Muhammadiyah, diakses tanggal, 11, 394399.

Schieve, L. A., Blumberg, S. J., Rice, C., Visser, S. N., \& Boyle, C. (2007). The relationship between autism and parenting stress. Pediatrics, 119 (Supplement 1), S114-S121

Safaria, T. (2005). Autisme: pemahaman baru untuk hidup bermakna bagi orang tua. Graha IImu.

Santrock, J. W., 2007. Perkembangan Anak. 2 ed. Jakarta: Erlangga.

Supriati, L., \& Selvitriana, D. R. (2018). The Relationship of Family Support with SelfEsteem Level in People Living with HIVIAIDS (PLWHA) in Sadar Hati Foundation Malang. Journal Nursing Care and Biomolecular, 3(1), 6-14.

Tehee, E., Honan, R., \& Hevey, D. (2009). Factors contributing to stress in parents of individuals with autistic spectrum disorders. Journal of Applied Research in Intellectual Disabilities, 22(1), 34-42.

Asri Mutiara Putri1Program Studi Psikologi FK Universitas Malahayati, Bandar Lampung. Email: asri.mp@gmail.com Woro Pramesti2Rumah Sakit Umum Ahmad Yani, Metro Lampung.

Rani Dwi Hapsari3 ${ }^{3}$ Program Studi S1 Kedokteran FK Universitas Malahayati Bandar Lampung . Email: ranidwihapsari01@gmail.com 